\title{
Curriculum Supervision and Implementation in Kenya: The Role of Secondary School Heads
}

\author{
Dorothy Owuor Jonyo, PhD \\ Bonn Odera Jonyo, DBA \\ United States International University-Africa, Kenya
}

Doi: 10.19044/ejes.v6no2a4

URL:http://dx.doi.org/10.19044/ejes.v6no2a4

\begin{abstract}
This is a conceptual paper which reviewed the role of secondary school heads in curriculum supervision and implementation in Kenya. The main objective is on the process of execution of the curriculum with a particular emphasis on the role of secondary heads in the supervision. The paper highlights the theory which curriculum is grounded and the various perspectives by scholars over the years. The paper delves in the background, the rationale, implementation and the process including the relevant legislations. The method used was relevant scholarly publications and TSC Act. The theory used is a more instrumental way to legitimize what is considered the 'right way' to execute. From the discourse, it is apparent that there is a strong agreement among curriculum implementers that the major purpose of curriculum supervision include monitoring performance, sharing information and solving problems. We recommend that the procedure used by the supervisors should be discussed, and agreed upon by the supervisees and that curriculum cannot be discussed in isolation without elucidating the roles of the head teachers in secondary schools.
\end{abstract}

Keywords: Curriculum, supervision, implementation, process, practice, functions.

\section{Introduction}

According to Morrison (2010), complexity theory explains the curriculum phenomenon. Several perspectives and ground rules for curriculum theory building have been advanced and can be summarized by five generalizations: Curriculum theory ought to begin by defining its set of events. Curriculum theory ought to make clear its accepted values and sources for making decisions. Curriculum theory ought to specify the characteristics of curriculum design. Curriculum theory ought to describe the essential processes for making curriculum decisions and the interrelationships among 
those processes and lastly, Curriculum theory ought to provide for continuous regeneration of curriculum.

Curriculum supervision is a program that prepares individuals to superintend instructional and support personnel at the school building, facility or staff level. It includes instruction in the principles of staffing and organization, the management of learning activities, personnel relations, administrative duties related to departmental or unit management, and specific applications to various educational settings and curricula (National Center for Education Statistics, 2018). Curriculum supervision therefore involves observation of teaching and learning, assisting teachers in their professional development, both in individual and group context, evaluation of teachers, research and revision of the curriculum (Education Encyclopedia, 2017).

Most post-modernists have criticized the models of supervision as being rigid, classified and authoritarian. Supervision represses the teachers' independence and hypothesize further that rational-technical formations of supervision lessen effectiveness to routines which turn supervisors into domineering with the authority to diagnose teachers' pedagogical lapses and impose solutions (Glanz \& Heinmann, 2018). Ovando (2000), on the other hand compliments effective supervision, and maintains that instructors, including teachers, curriculum specialists, and supervisors would collaborate in order to improve instruction. Cobbold, Kofie, Bordoh, and Eshun, (2015). advances that curriculum supervision, is a method of teaching the staff to act in a more cognizant way. Its goal is to provide curriculum implementers and supervisors with more information and unfathomable insights into what is happening around them. This increases options for instructors to work with students and superiors to facilitate effective partnership between curriculum leaders as supervisors, as teachers learn to identify and resolve their challenges. Subsequently supervisors get a new perspective about what happens in different classroom environments. Supportive supervision is a learning situation for both teachers and their supervisor.

However, to others (mostly staff and students), supervision could lead to some curriculum leaders overstepping their role expectations just to teach one a hard lesson or show where power lies. Very critical is the issue of trust between the supervisor and supervisee otherwise there is bound to be a very poor relationship, unfriendliness and suspicion.

Print (1993) defines curriculum as all planned activities which are consciously organized and systematically implemented under careful watch of instructors in the school. In other words, all conditions which yield learning by reason of the structure and organization, as well as peculiar practices of the school within and without the classroom, official timetable or the syllabus are deemed to have greater effect. Practices and activities which may be described 
as extracurricular or co-curricular are considered as important as those officially presented in documents.

Additional perspective of the curriculum is the totality of how learning experiences harmonizes with broad view or generalist perspective of curriculum development. It depicts curriculum as presenting opportunities and avenues by educational delivery systems through which learners attain knowledge forms, skills, values and attitudes which contribute to effective living, but not necessarily prescribed for certification. This means therefore that, learners gain experiences and develop, not only through prescribed content, but also through procedures of instructions, modes of enquiry, personal and organized interactions within the social and physical environments of learner. Curriculum experience may, hence, be gained through the planning of field trips, supervised projects, industrial attachments and competitive field games. In classroom scenarios, apart from the prescribed content itself, a wide range of techniques such as experimental procedures, role play, simulations, and group work are vital for total learner development.

Holloway (1995) proposes that, the supervisor should function in an ideal professional behavior and practice, both covertly in the managerial connection and overtly by role-playing for the supervisee.

This reduces interpersonal distance and makes exercise of power a collaborative process. This, however, requires the trust and respect of the supervisee(s) in order to engage in a more collaborative rather than antagonistic relationship.

\section{RELEVANT LITERATURE Rationale for Supervision}

According to Hawkins and Shohet (2012), the critical focus of curriculum supervision envisages;

$>\quad$ Orderly environment for supervisees to replicate the content and process of their work.

$>\quad$ Development of skills, receiving information, other perspectives concerning the teacher's work, evaluation and feedback. This ensures that the teacher is validated and supported both as an individual and as a teacher.

$>\quad$ Exploration and expression of personal distress, re-stimulation, change as a consequence.

$>\quad$ Enhancing planning and utilization of the soft skills and professional capital of teachers.

$>\quad$ Ensure quality of work-specific references to functions or purposes of curriculum supervision. This includes improvement in classroom teaching and learning, assisting teachers in professional and group development, evaluation of teachers' work output, research and revision of the curriculum. 
$>\quad$ Maintaining of standards or benchmarks, meeting delivery targets within timeframes, as well as checking resistance in teachers and learners. This calls for the need to be abreast with what constitute the historical overview of curriculum supervision.

The phenomenon of curriculum supervision therefore exists within school management, monitoring or even inspection. It must be emphasized that curriculum supervision as a field of educational endeavor with clearly delineated roles and responsibilities has also evolved slowly as a distinct practice, always in relation to the institutional, academic, cultural and professional dynamics that have historically generated the complex agenda of schooling (Education Encyclopedia, 2017). Once proper supervision has been done implementing the curriculum comes automatically as the teacher is armed with all the necessary tools.

\section{METHODOLOGY}

References was made on scholarly publications, TSC Act and several Ministry of Education Science and Technology reports.

\section{Curriculum Implementation}

Curriculum implementation involves the practice of formally approved courses of study, syllabuses and subjects. The learner acquires knowledge or experience through an organized environment with instructors with a set of prescribed rules and regulations. The centrality of the learner is emphasized in the curriculum implementation process. The process of implementation takes place as the learner acquires the planned experiences, knowledge, skills, ideas and attitudes (University of Zimbabwe, 1995). This perspective emphasizes also that curriculum implementation is an educational programme when put into effect.

\section{THE PROCESS \\ Supervision/Implementation}

The Teachers Service Commission (TSC) is committed to effectively manage the teaching service for quality education in line with provision of the Constitution of Kenya which recognizes that Secondary schools play a vital role in improving the quality of lives of Kenyans. Pursuant to section 11(f) and 35 (i) of TSC Act (2012), the Commission is mandated to monitor the conduct and performance of teachers in the teaching service. When signing the performance contract, the head teacher signs a 'Statement of Responsibility' where he /she states that as a head teacher, it is his/her undertaking to provide the required leadership in designing suitable plans and strategies to deliver educational services and enable this school realize its goals. In this regard, the Commission has introduced an open Performance 
Appraisal System for teachers to strengthen supervision and to continuously monitor their performance in curriculum implementation at the institutional level. The appraisal system shall be used to provide feedback, improve communication, and clarify roles and responsibilities detailed below:

The school management is directly involved in curriculum implementation and supervision. This is the basic operation area of all school administration. Owen (1992) submits that all school managers must ensure the improvement in instruction by developing effective instructional leadership on the part of the head teacher. The head teacher must ensure that the educational objectives of their school and the means of achieving them are clearly spelt out by the professional staff. Ensure effective teaching is observed in the school through regular supervision of classroom instruction. As a school manager the head teacher should make teaching possible by stimulating desired changes in the professional behavior of the teachers. Effective instructional leadership demand that he or she must be a competent teacher and should keep abreast to recent developments in curriculum in general and instruction supervision in particular.

The Teacher Appraisal Performance and Development (TPAD) Tool for Heads (TSC/QAS/TPAD-HPSS/03), contains seven teaching standards with the first being professional knowledge and application where the head teacher should have the ability to prepare and supervise;

$>\quad$ Preparation, maintenance and use of professional documents.

$>\quad$ Learner's internal evaluation through development of testing policy for the school and management of national exams.

$>\quad$ Maintenance and tracking of learner's value added progress (VAP) records, Individualized Education Programs (IEP).

In particular, the head teacher must check the teaching standards by reference to scheme of work, lesson notes, and records of works, student's exercise books, and also participate in classroom observation. The head teacher has a role of selecting, producing and supervising locally available instructional materials/resources which will be beneficial to the teacher in curriculum delivery and improve instruction through effective instruction leadership This means that effective and efficient running of the school depends on the head teacher's instructional management role. The head teacher must schedule, assign work, coordinate and oversee performance and make sure that work is done in time.

As a head teacher one should have the ability to ensure effective time management through monitoring;

$>\quad$ Teacher presence and attendance to duty.

$>\quad$ Teacher lesson attendance.

$>\quad$ Adherence to school timetable - Attendance to all other school activities eg staff meetings, AGMs, academic clinics, co-curriculum activities. 
Knowledge of child protection and safety legal provisions is imperative to curriculum implementation. It is necessary because when the learning environment have no safety measures and not child friendly, proper learning will not take place. It's the duty of the head teacher of the institution to ensure that there is compliance with the Children's act, Sexual offence Act. TSC Act, CORT, COCE. Equally important is learner discipline and teacher conduct in the school. All teachers and stakeholders should be sensitized on the above mentioned documents.

Co-Curricular activities in the learning institutions should be supported, coordinated together with life skills education for nurturing of talents among learners. Games, clubs and societies should be taken seriously and students encouraged to join and participate in the various activities in the school.

The success of any learning institution depends on the ability of its leadership to collaborate with patents/guardians and stake holders. This can be done by involvement in community development based activities, exchange programmes and national initiatives like tree planting, advocacy against FGM, drug and substance abuse, HIV and AIDS sensitization and prevention. All these lead to the improvement in teaching and learning, the basis upon which the head teacher performance is evaluated.

Secondary education mainly caters for primary school leavers ranging between 14-18 years. It is both terminal and preparatory for learners who proceed to the university or middle level colleges for further education and training. It therefore plays an important role in preparing learners either for the society or for further education and training. Ministry of Education Science \& Technology (MoEST) launched the Transition Infrastructure Grants (TIG) in 2016 to have all primary school leavers enrolled into secondary schools. In July 2018, the Teachers Service Commission hired 8,672 teachers to support this Government policy on 100 per cent transition drive from primary to secondary schools launched in January 2019. The new teachers are supposed to plug a severe staffing shortage in public secondary and primary schools estimated to be 155,000 , said TSC chief executive Dr. Nancy Macharia. The commission had asked the government for Sh8.3 billion to recruit 12,626 secondary teachers annually for four years, translating to 50,504 teachers to support the transition but the Government only gave Sh4.7 billion, according the year's budget policy statement. This shows that transition from primary to secondary level has tremendously increased. The head teachers therefore need to double their supervisory role in order for students to realize high academic achievement and actualize for this goal. As a manager therefore, the head teacher should explain tasks to the staff and make follow up accordingly.

In terms of teacher appraisal, the head teacher should have the ability to manage the appraisal process, identify gaps and based on these gaps develop 
and implement a School Based Teacher Professional Development a (TPD) plan. The current introduction of performance contract by TSC requires head teachers to acquire more knowledge, skills and experience. According to Wideen, (1987), "schools now require that even experienced principals improve their leadership skills through seminars, workshops and refresher courses on classroom organization, teaching methods outcome based instruction and teacher evaluation". In analyzing the curriculum that the school wishes to deliver and the associated management structure needed to support it, Head teaches should strive to attend professional courses in matters related to curriculum instruction management. The country looks upon them to give guidance and direction otherwise the national examinations in secondary schools will always register improvement or decline depending on their commitment to the curriculum instruction management roles they undertake in their schools.

Peer classroom observation should be encouraged in the school but the head teacher can also do classroom observation in his school using the classroom observation tool designed by the TSC as part of its appraisal system with five observation areas namely;

$>\quad$ Introduction and lesson organization.

$>$ Content delivery.

$>\quad$ Teaching methods/techniques.

$>\quad$ Learner involvement and communication.

$>\quad$ Classroom management.

There should always be a preparatory meeting before the lesson observation and a feedback session after the lesson observation. Establish good relationship with the teacher, informing the observing the teacher's performance in class, meeting the teacher in a quiet place after observation to advice the teacher accordingly. This should never be a fault finding session but a time to reflect on the strengths, weaknesses of the teacher and how to improve on them. The head teacher needs to explain to the teacher the purpose of the classroom visits to enable him/her understand the educational programme. Chiemela (2010) emphasizes that when the head teacher observes the teaching learning process he/she should have specific items (checklist) to observe like methods presentation, motivation for learning aids student interest and attention, classroom atmosphere, this ensures that the head teacher has a criterion for judging each area of the teacher's performance.

UNESCO (2018) observes that staff members will perform effectively when they are motivated in terms of; good salary, job security, regular consultation with the head, their work being appreciated, fact full discipline and when they receive sympathetic help when dealing with problems. Some of the ways in which a head teacher can meet his staff motivational needs according to the MoEST (2018) include: 
$>\quad$ Giving teachers a chance to attend in- service training and other activities.

Delegating important responsibilities such as chairing subject panels · Inviting role models to talk to teachers, students and supportive staff . Recognition of teachers during AGMs and other for a Good management and best practice requires head teacher to act and disseminate information promptly to avoid breakdown of communication. The head teacher should ensure good communication so that the teachers are fully informed of what is going on in the school. The manager should develop and maintain a system of communication that provide for an upward flow to benefit decision making, a downward flow to benefit the implementation of policy, and a horizontal flow to facilitate coordination of all departments of the organization. Emerson (1993) observes that successful communication requires that every member of the organization has all the information required at the appropriate time in order to undertake their duties. However successful communication demands that all members shall have the opportunity to question, comment, inform and engage. Staff relations are influenced by communication, failure to which there can be misunderstanding among the staff members. UNESCO (1993) observes that the head teachers require both oral and written communication skills in order to communicate effectively to all stake holders at different times.

$>\quad$ Effective communication helps to control behaviour.

$>\quad$ It provides feedback to the personnel on how to improve.

$>\quad$ It facilitates decision making and fulfil the social need of expression of feelings.

Oral communication can be done in assemblies, while written communication can be done through proposals, report, minutes, internal memo and correspondence, newsletter, suggestion box, fax, telex. To ensure effective communication, the head should ensure clarity of information and civil language. He/she should choose an adequate channel to communicate, communicate in time for the appropriate response and provide a proper atmosphere for feedback.

Wideen (1992) observes that, the teacher is the central figure in curriculum and school development. There can be no development without the development of the teacher. A teacher who is not growing professionally is unlikely to make significant development improvement in the classroom programmes. For education to meet both the rapid requirement of the demand for new curriculum and methods of teaching the teachers have to be empowered through training. In the Performance Contract signed by the head teachers and the Teachers Service Commission at the beginning of every year, Performance Criteria C4 states that the head teacher is expected to promote Teacher Professional Development (TPD) at the school level by; 
Identifying teachers' professional gaps (challenging areas in pedagogy, subject content and learners' management that hinders them from effective delivery of curriculum) - Developing TPD programmes at school level to mitigate teachers' professional gaps.

Monitoring teachers' progress in school planned TPD.

Maintaining records of TPD.

The head teacher must accept accountability over all training, this may involve targeting training priorities, making time and resources available for training.

\section{Conclusion}

From the above discourse, it is evident clearly that we cannot talk of curriculum supervision and implementation without elucidating the head teacher roles. He /She is the engine behind the curriculum implementation and is responsible for all matters pertaining to the smooth running of the school. The priority of any government is to improve the quality of education offered and students achievements. The Kenya government therefore rely strongly on the school supervision system to monitor and evaluate both quality of schools and key measures of its success such as student achievement.

The Head teacher plays a major role in effective implementation because he is the person most likely to shape the Institution's conditions necessary for the success, such as development of shared goals, work structure, climate and procedures for monitoring results. He /She is an administrator, problem solver and a facilitator for change.

\section{References:}

1. Awiti, J. A., Onderi, H., \& Raburu, P. (2016). Head' Teachers" Supervision' of' Curriculum' Implementation:' Implications o' Provision' of' Quality Secondary Education in Kenya.

2. Chiemela, N. I. (2010). Instructional supervisory practices of Anambara state secondary

3. school principals. A comparison with desired instructional supervisory practices.

4. Unpublished Project. University of Alberta: Canada. Chan, 2004

5. Cobbold, C., Kofie, S., Bordoh, A., \& Eshun, I. (2015). Perception of curriculum leaders and teachers on feedback and conditions essential for effective supervision in senior high

6. schools. International Journal of Educational Research and Information Science, 2(2), 21-26.

7. Complexity Theory and Macao's School Curriculum Management System. Available from: 
https://www.researchgate.net/publication/261637035 [accessed May 14 2019].

8. Education

Encyclopaedia

$(2017)_{2}$

https://www.newworldencyclopedia.org/entry/Education

9. Emerson, C (1993). Managing Staff in School. Paris: Athenaum press Ltd.

10. Glanz, J., \& Heinmann, R. (2018). Encouraging reflective practice in educational supervision

11. through action research and appreciative inquiry. In S. Zepeda \& J. Ponticell (Eds.), The

12. Wiley handbook of educational supervision. New York: WileyBlackwell.

13. Hawkins, P. \& Shohet, R. (2012). 4 Supervision in the helping professions: An individual, group and organizational approach, Milton Keynes: Open University Press.

14. Holloway, E. (1995). Clinical supervision: A systems approach. Thousand Oaks: 2 Sage Publications Inc

15. Maranga, J. S. (1993). Guidelines for Training Educational Supervisors in Kenya, Columbia University.

16. Mbiti, D. M. (1999): Foundation of School Administration. Nairobi: $\underline{5}$ Oxford University Press.

17. MoEST (2017) Education Report

18. Morrison, K. (2010), Complexity Theory, School Leadership and Management: Questions for Theory and Practice; https://doi.org/10.1177/1741143209359711

19. National Center for Education Statistics, (2018).

20. Ovando, M., (2000), In J. Glanz and S. L. Behar-Horenstein. Debates in curriculum and supervision. Westport: C.T Publications

21. Owen, J (1992). Managing Education. The Purpose and Practice of Good Management in Schools. Longman, London.

22. Print, M. (1993). 5 Curriculum development and design (2nd ed.). St. Leonards, NSW: Allen \& Unwin.

23. Teachers Service Commission. (2013). Annual Report 2012/2013. Nairobi: TSC.

24. Teachers Service Commission. (2014). TSC Act 2012 Revised Edition. Nairobi: National Council of Law Reporting.

25. Teachers Service Commission. (2015). Annual Report 2014/2015. Nairobi: TSC.

26. Teachers Service Commission. (2016). Annual Report

27. TSC/QAS/TPAD-HPSS/03 (2018) ... Teacher Performance Appraisal and Development. 
28. 2019 Global Education Monitoring Report,m Regional Launch Nairobi, Kenya - 20 November 2018.

29. Wideen, F. M. (1992). The Staff Development for School Improvement. A Focus on the Teacher, New York: London Simon Fraser Press. 